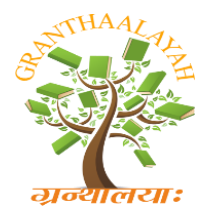

INTERNATIONAL JOURNAL OF RESEARCH GRANTHAALAYAH

A knowledge Repository

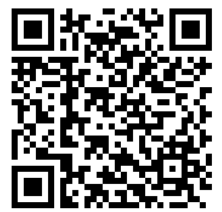

Management

\title{
TO STUDY THE IMPACT OF DETERMINANTS OF GROWTH ON FIRM'S PERFORMANCE WITH RESPECT TO IT INDUSTRY
}

\author{
Dr. Mayank Saxena ${ }^{* 1}$, Mr. Sumeet Maru ${ }^{2}$ \\ ${ }^{* 1}$ Professor \& Principal, Management, Indore Institute of Management \& Research, INDIA \\ ${ }^{2}$ Founder, CH Group, INDIA
}

\begin{abstract}
Firm growth is an important indicator of a thriving economy. Although the determinants of firm growth have been studied in various disciplines, an integrated analysis is still lacking. Many determinants of firm growth are summarized and classified into three dimensions: individual, organizational, and environmental determinants. The present paper attempts to provide an integrated analysis on the determinants of firm growth. It gives an opportunity to investigate the determinants of firm growth in a comprehensive way.

The close-ended questionnaire was developed from standard questions of relevant literature as a research instrument. The sample size taken for the research is of 110 IT firms entrepreneurs.

Among the individual determinants, need for achievement, risk taking propensity and selfefficacy are positively conducive to firm growth. Among the organizational determinants, formulation, preparedness to grow, organizational learning, financial performance have positive impacts on firm growth. Market orientation, Entrepreneurial orientation, competitive intensity shows a negative relationship. Among the Entrepreneurial determinants, munificence, heterogeneity has positive impacts on firm growth. Market dynamism shows a negative relationship. Growth Barriers shows negative relationship.

Our study shows that firm growth is a complex phenomenon. It cannot be explained by one particular dimension or one determinant. The most important determinants have been identified from the individual, environmental and organizational dimensions. Organizational determinants have the greatest influence on firm growth.
\end{abstract}

Keywords:

Entrepreneurship, Individual Determinants, Organizational Determinants, Environmental Determinants, Linear Regression.

Cite This Article: Dr. Mayank Saxena, and Mr. Sumeet Maru, "TO STUDY THE IMPACT OF DETERMINANTS OF GROWTH ON FIRM'S PERFORMANCE WITH RESPECT TO IT INDUSTRY" International Journal of Research - Granthaalayah, Vol. 4, No. 1 (2016): 108-118. 


\section{INTRODUCTION}

Entrepreneurship is crucial to increasing productivity, competition, and innovation; is valuable to an economy and its participants (US, Office of the Press Secretary, 2003); creates thousands of jobs each year (Morris \& Kuratko, 2002); and increases prosperity and revitalizes communities. Since the first (US) entrepreneurship course was taught in 1947 at Harvard Business School, the entrepreneurship field has grown extensively. There has been growth in entrepreneurship course offerings and the number of entrepreneurship faculty, endowed positions, academic journals, conferences, books, and research centers (Katz, 2003).

In India the term entrepreneurship connotes a restricted meaning. It generally veers round efforts which result in establishing and running factories and industrial enterprise alone. Moreover, there is a market tendency to relate it only to operations, which exceed a particular size. This narrow overview of the concept perhaps reflects the preponderance of values nurtured by urban white collar class in the society. Secondly entrepreneurship has been viewed as a phenomenon occurring around the individual and benefiting only an individual (Singh, 1992). Harbinsen (cited by Singh 1992) defines entrepreneurship as a skill to build an organization. He spots the crux of entrepreneurship in the ability to multiply by effectively delegating responsibilities to others. He further stresses that the ability to create an organization is the most crucial skill as it facilitates the economic use of other innovations and that in the absence of this skill other innovations fail to stimulate economic development.

Under planned economy, India has achieved remarkable progress in all spheres of economy. It has developed almost all sectors of the economy and succeeded in achieving the high levels of production, income and consumption. The rate of capital formation has considerably increased and the levels of savings and investments have also improved. The industrial sector of the country has shown significant progress in the field of production, employment and income generation. After introduction of economic reforms and the policies of globalization, privatization and liberalization, the scope of economic development, modernization, diversification and expansion has enlarged the fields of economic activities. Rapid progress in the field of science and technology has expanded the scope of innovations in production, process and techniques (Srinivasan, 2007).

Entrepreneurship researchers have indicated that growth is a crucial indicator of venture success, more crucial than other performance indicators (Covin and Slevin, 1997, Low and MacMillan, 1988). There is a group of researchers who focus on concepts that explain growth, i.e. what are the antecedents of organisational growth? And what are the consequences for the company itself? In this section a short overview is presented of determinants for growth from literature on strategic management and entrepreneurship. Philipsen and Kemp (2003) present an overview of both theoretical and empirical studies on determinants for growth.

The present paper attempts to provide an integrated analysis on the determinants of firm growth. It gives an opportunity to investigate the determinants of firm growth in a comprehensive way. 


\section{LITERATURE REVIEW}

In order to summarize the determinants from a wide range of perspectives, we classify these determinants into three dimensions, namely, individual determinants, organizational determinants and environmental determinants. In addition, we also include 'negative' determinants, titled as growth barriers. These determinants are discussed as follows:

\section{INDIVIDUAL DETERMINANTS}

The growth of a firm is to a certain extent a matter of decisions made by an individual entrepreneur. Previous studies indicate that an entrepreneur's personality traits, growth motivation, individual competencies and personal background are the most important determinants that determine the growth of a firm (Baum et al., 2001; Delmar, 1996; Shane, Locke \& Collins, 2003).

\section{Need for achievement}

McCelland argues that individuals with a high degree of need for achievement to engage in activities or tasks are more likely to take greater responsibility for outcomes than those who have a low degree of need for achievement (McClelland, 1965). Lau and Busenitz (2001) found a strong positive relationship between the need for achievement and the ambition to grow the firm. Hence, we can imply that there might be a positive relationship between need for achievement and firm growth.

\section{Risk taking propensity}

Risk taking propensity seems to be an important trait of an entrepreneur. An entrepreneur can be characterized as someone who seeks opportunities, faces uncertainties and takes risks (Venkataraman, 1997). It has been indicated that owners of young and established firms who are not risk averse are more likely to be ambitious to grow the firm (Bager \& Schøtt, 2004). Entrepreneurs also encounter various types of risks. Some of these risks might have direct effect on their behaviour, while some might not. Nevertheless, based on the relationship between risk taking propensity and growth ambition, we propose a positive impact of risk taking propensity on firm growth.

\section{Self-efficacy}

Self-efficacy is defined as an individual's ability to gather and implement the necessary personal resources, skills and competencies in order to achieve a given task (Bandura, 1997). Self-efficacy has proved to be a robust predictor of an individual's performance for a specific task (Shane et al., 2003). Growth is an important indicator of individual performance, specifically if the individual is an owner of a small business. One can argue that an individual with high selfefficacy for a given task will put more effort and time into it, make better plans and strategies, self-evaluate and modify goals if necessary to successfully accomplish the task.

\section{ORGANIZATIONAL DETERMINANTS}

Firm growth is an increase in certain attributes, such as sales, employment, and/or profit of a firm between two points in time (Hakkert \& Kemp, 2006). Firm growth can be determined by the 
degree of effectiveness and capability with which firm-specific resources such as labour, capital and knowledge are acquired, organized, and transformed into sellable products and services through organizational routines, practices, and structure (Nelson and Winter, 1982; Nickell, 1996; Nickell, Nicolitsas, \& Dryden, 1997). Thus, organizational determinants should have more direct impacts on firm growth.

\section{Formalization}

Formalization refers to the extent to which organizational rules, procedures, authority relationship, communication, and norms are defined (Hall, Haas \& Johnson, 1967). Formalization along with standardization and coordination are utilized to control and optimize organizational procedures. The effect of organizational structure on firm growth is rather complex due to the dependencies on other factors such as firm size, sector, and organizational configuration, it is suggested that including them in studies could give a better understanding of the determinants of firm growth.

\section{Organizational learning}

Organizational learning serves similar aim of knowledge creation as does R\&D. While R\&D brings in or creates explicit and technical knowledge within firms, organizational learning externalizes the tacit knowledge embedded into individuals and specific groups to organizational knowledge. Knowledge is a key source of a firm's competitive advantage (Barney, 1991; Grant, 1991) and it is especially crucial for innovation (Cohen \& Levinthal, 1990). Through learning processes, an organization's stock of knowledge can be created and expanded. Consequently, overall quality of organizational knowledge can be leveraged (Hult et al., 2003).

\section{Market Orientation}

Firm growth can be determined by how successfully one sells products and services to the customers. Therefore, market orientation can be considered an important determinant of growth. Firms with market orientation are able to track and respond to the customer's needs and preferences. They are more likely to develop their market intelligence as well as have the ability to coordinate internal processes in order to respond quickly and effectively to customers and external stakeholders. Consequently, market orientation enables better satisfaction of customers and stakeholders which in turn result in a firm's growth (Hult, Snow \& Kandemir, 2003; Narver \& Slater, 1990).

\section{Entrepreneurial orientation}

Entrepreneurial orientation is defined as innovation, proactiveness and risk taking on the firm level (Miller, 1983). The concept is further developed into five dimensions with the additional dimensions of autonomy and competitive aggressiveness (Lumpkin \& Dess, 1996, 2001). Autonomy is defined as independent action by an individual or a team aimed at bringing forth a business concept or vision and carrying it through to completion. Risk taking means a tendency to take bold actions such as venturing into unknown new markets, committing a large portion of resources to ventures with uncertain outcomes and/or borrowing heavily to invest in business. Proactiveness is an opportunity-seeking, forward-looking perspective involving introducing new products or services ahead of the competition and acting in anticipation of future demand to create change and shape the environment. Competitive aggressiveness reflects the intensity of a 
firm's efforts to outperform industry rivals, characterized by a combative posture and a forceful repose to competitor's actions.

\section{Financial resources}

Financial resources might be particularly important in promoting firm growth (Bamford, Dean \& McDougall, 1997; Sexton \& Bowman-Upton, 1991). It is because financial resources can relatively easily be converted into other types of resources (Dollinger, 1999). With sufficient resources, firms are able to experiment new things, which not only increases their innovation potential but also enables the business to pursue new growth opportunities (Castrogiovianni, 1996; Zahra, 1991). Empirical studies show that access to financial resources has a positive effect on small business growth (Cooper et al., 1994; Storey, 1994). Financial performance of a firm is a secondary input to the financial resources for firms. Profit yielded in the past can be reinvested into the firm. By this means, a firm not only relies on external funding, but instead also uses internal funds to finance investments.

\section{ENVIRONMENTAL DETERMINANTS}

A general finding in literature is that most firms start small, live small and die small. One major reason for this is that a majority of the business start-ups are imitative businesses in mature industries that serve local markets (Audretsch \& Mahmood, 1994; Baldwin \& Gellatly, 2003). Samundsson and Dahlstrand (2005) found that firms seeking to exploit opportunities based on new market knowledge are less likely to attain substantial growth than firms seeking to exploit opportunities based on existing market knowledge.

\section{Dynamic environment}

Dynamic environment either market dynamics or technology dynamics, is measured by the level of environmental predictability (Houston, 1986). It is argued that there are more opportunities for growth when there are changes in society, politics, market and technology (Wiklund et al., 2007).

\section{Munificence}

Munificence represents an environment's support (for example, great market potential) for firm growth (Aldrich \& Wiedenmayer, 1993). A firm in such an environment with better access to required resources has higher chances to grow. Unfortunately, a previous study shows a slightly significant direct effect of munificence on firm growth (Baum et al., 2001).

\section{Heterogeneity}

Heterogeneity indicates the complexity of environment regarding the concentration or dispersion of organizations in the environment. It is argued that small firms which serve niche markets can find growth opportunity with relatively more ease in a heterogeneous market than in a homogeneous one (Wiklund et al., 2007).

\section{GROWTH BARRIERS}

While the aforementioned determinants generally facilitate firm growth, there are also factors that hinder potential growth (Davidsson, 1989). Such factors are titled as growth barriers. It is 
argued that SMEs are more likely to face entry barriers and growth barriers compared to their large counterparts. Commonly addressed barriers for small businesses include institutional barriers and financial barriers. Institutional barriers are mainly discussed with the focus on firms' interaction with government, including legalization, taxation, and government support amongst others. Based on consistent results from both theoretical and empirical data, Davidsson and Henreksson (2002) strongly argue that certain institutions intentionally discriminate against the growth of SMEs which in turn act as a growth barrier. It is not difficult to imagine that SMEs would have a tough period when they face unfavourable tax system, discriminatory regulations and complicated laws. Financial barriers represent lack of financial resources. It has been argued that credit constraints, lack of external debt, and equity capital are the main obstacles to the growth of SMEs (Becchetti \& Trovato, 2002; Pissarides, 1998; Riding \& Haines, 1998). Furthermore, SMEs could also face external barriers, internal organizational barriers and social barriers which cover aspects of market position of a firm, access to qualified human capital, and access to network (Bartlett \& Bukvič, 2001).

\section{STATEMENT OF PROBLEM}

This research focuses on the key determinants of the growth of the IT companies. It aims to explain the reasoning and the driving forces behind the growth that have taken place in the IT companies in Madhya Pradesh. The main interest is in describing the key determinants of growth and analyzing the real-life effects of those determinants on the IT companies. The main research question of this paper is how was the performance of firm affects by the determinants of growth in Indian IT companies?

\section{HYPOTHESIS}

H1: There is no significance impact of need for achievement on firm's performance

$\mathrm{H} 2$ : There is no significance impact of Risk taking propensity on Firm's Performance

H3: There is no significance impact of Self efficacy on Firm's Performance

H4: There is no significance impact of Formulation on Firm's Performance

H5: There is no significance impact of Market orientation on Firm's Performance

H6: There is no significance impact of Entrepreneurial orientation on Firm's Performance

H7: There is no significance impact of preparedness to grow on Firm's Performance

H8: There is no significance impact of Organizational learning on Firm's Performance

H9: There is no significance impact of financial performance on Firm's Performance

H10: There is no significance impact of Competitive Intensity on Firm's Performance

H11: There is no significance impact of Market Dynamism on Firm's Performance

H12: There is no significance impact of Munificence on Firm's Performance

H13: There is no significance impact of Heterogeneity on Firm's Performance

H14: There is no significance impact of Growth Barriers on Firm's Performance

\section{RESEARCH METHODOLOGY}

Research Design \& Sampling design: This research study is of descriptive nature and has used both the quantitative and qualitative research method. A convenience sample is employed for sampling method from Indore area and responses are taken from IT entrepreneurs. Size of the universe cannot be defined because every individual could be a respondent for this particular 
study. The sample size has been consisting of 130 respondents. Of the 130 data sets, 20 were eliminated because of high missing data. Therefore, 110 usable data sets were entered into the data analyses.

The close-ended questionnaire was developed from standard questions of relevant literature as a research instrument. However, secondary data has been collected with the help of print media like books, magazines, research articles on Google scholars and such other websites, related company literature. The Linear Regression analysis technique is used for data analysis. The statistical Package for the Social Sciences Program (SPSS) version 19.0 was used in this study for all the statistical assessments. The data set was screened and examined for incorrect data entry, missing values, normality and outliers. In this study, descriptive statistics are first employed and then linear regression analysis is carried out by the researcher.

\section{RESULTS}

Fourteen determinants are identified to have significant impacts on firm growth. Among the individual determinants, need for achievement $(B=7.395, \mathrm{p}<0.001)$ and risk taking propensity $(B=4.715, p<0.01)$ and self efficacy $(B=0.574, P<.01)$ are positively conducive to firm growth.

Among the organizational determinants, formulation $(\mathrm{B}=11.684, \mathrm{p}<.01)$, preparedness to grow $(\mathrm{B}=0.380, \mathrm{p}<0.01)$, organizational learning $(\mathrm{B}=0.505, \mathrm{p}<.01)$, financial performance $(\mathrm{B}=0.571$, $\mathrm{p}<0.001)$ have positive impacts on firm growth. Market orientation $(B=-9.729, p<.001)$, Entrepreneurial orientation $(B=-0.878, p<.01)$, competitive intensity $(B=-11.953, p<.001)$ shows a negative relationship.

Among the Entrepreneurial determinants, munificence $(B=0.152, p<.01)$, heterogeneity $(\mathrm{B}=0.183, \mathrm{p}<.01)$ have positive impacts on firm growth. Market dynamism $(\mathrm{B}=-0.618, \mathrm{p}<.001)$ shows a negative relationship. Growth Barriers $(B=-2.583, \mathrm{p}<.01)$ shows negative relationship.

\section{DISCUSSION \& LIMITATIONS}

In this paper, investigate the determinants of firm growth. This gives an opportunity to evaluate the importance of all dimensions as well as all underlying determinants. The research identifies the most important determinants of firm growth using a simple model.

Among the individual determinants, our empirical results show a positive relationship between growth motivation and firm growth. It has been argued that a motivated entrepreneur will perform better in firm growth since he/she will devote more time and energy. Our empirical results also show that the entrepreneur's specific skills, specifically the technical background, have a significant impact on firm growth. From a learning perspective, entrepreneurs with technical background can learn managerial skills via daily operations. However, it may be more difficult for a non-technical entrepreneur to understand the technical aspects. Furthermore, technically accomplished entrepreneurs are more aware of the technical opportunities. Our findings support that technical competency is an important expertise which facilitates the implementation of the entrepreneur's vision and strategy. 
Organizational determinants have the greatest influence on firm growth. Our findings support the path-dependency feature of firm growth. Most of our empirical findings support previous studies. Among the individual determinants, our empirical results show a positive relationship between growth motivation and firm growth. It is consistent with the motivation theory. It has been argued that a motivated entrepreneur will perform better in firm growth since he/she will devote more time and energy. The empirical results also show that the entrepreneur's specific skills, specifically the technical background, have a significant impact on firm growth. From a learning perspective, entrepreneurs with technical background can learn managerial skills via daily operations. However, it may be more difficult for a non-technical entrepreneur to understand the technical aspects. Furthermore, technically accomplished entrepreneurs are more aware of the technical opportunities. Our findings support that technical competency is an important expertise which facilitates the implementation of the entrepreneur's vision and strategy.

Among the organizational determinants, a negative effect of firm age on firm growth is found in our empirical study. This is in line with the view that younger firms feel the urge to reach the minimum efficiency scale and thereby exhibit higher growth rates compared to the older ones. The empirical results also show that both extra finance and financial performance are positively related to firm growth. This finding is in line with previous studies. Availability of capital is crucial for firm growth because it can be converted into other types of resources.

Firms with secured financial resources are able to experiment which consequently yields new opportunities for growth. The positive relationship between availability of capital and employment growth is also straightforward. The hiring of new employees will result into an increase in a firm's costs. Hence a firm will not be able to expand without a precondition of sufficient finance.

One of the novel findings of our empirical study is that there exists a positive relationship between preparedness to grow (as a firm's business model) and firm growth. A firm's business model has been sparsely discussed in the existing growth literature as an important determinant. A business model is a coherent framework that converts firm's resources and capabilities into economic value. An effective business model is a firm's ability to recombine its resources, structure, and strategy to yield valuable organizational outcomes. Firm growth is a likely outcome of an effective business model. This finding provides practical implications for entrepreneurs: entrepreneurs with growth ambitions should not only be solely based on a competitive strategy; they should also rationally evaluate the overall capabilities of the firm, in other words whether resources and organization structures of the firm are prepared for firm growth.

To conclude, our study shows that firm growth is a complex phenomenon. It cannot be explained by one particular dimension or one determinant. The most important determinants have been identified from the individual, environmental and organizational dimensions. Organizational determinants have the greatest influence on firm growth.

The limitations of the present study are the following: first, we develop a simple model which does not account for moderation and mediation effects. Several other studies that use a limited number of explanatory variables indeed indicate an existence of moderation or mediation effects 
between different determinants (Baum et al., 2001; Wiklund et al., 2007). Our empirical findings should be interpreted as a starting point to develop a more complex model to test those effects. Future study should include sales growth as a dependent variable. Also it will be more insightful if the interlinks between different growth indicators can be investigated. Third, the crosssectional nature of the data does not allow for dynamic aspects. The current setup can be extended to a longitudinal setup in future research.

\section{REFERENCES}

[1] Aldrich, H. E., \& Wiedenmayer, G. 1993. From traits to rates: an ecological perspective on organizational foundings. In J.A.Katz, \& R.H.Brockhaus (Eds.), Advances in entrepreneurship, firm emergence, and growth, Vol. 1: 145-195. Greenwich, CN: JAI Press.

[2] Audretsch, D. B., \& Mahmood, T. 1994. Firm selection and industry evolution: The postentry performance of new firms. Journal of Evolutionary Economics, 4: 243-260.

[3] Bager, T., \& Schфtt, T. 2004. Growth expectation by entrepreneurs in nascent firms, baby business and mature firms: analysis of GEM population data 2000-2003. In T.Bager, \& M.Hancock (Eds.), Global Entrepreneurship Monitor: 281-291. Denmark: Børsens Forlag.

[4] Baldwin, J., \& Gellatly, G. 2003. Innovation strategies and performance in small firms. Cheltenham, UK: Edward Elgar.

[5] Bamford, C. E., Dean, T. J., \& McDougall, P. P. 1997. Initial strategies and new venture growth: An examination of the effectiveness of broad vs. narrow breadth strategies, Frontiers of Entrepreneurship Research. Wellesley, MA: Babson College.

[6] Bandura, A. 1997. Self-efficacy: the exercise of self control. New York: Freeman.

[7] Barney, J. 1991. Firm resources and sustained competitive advantage. Journal of Management, 17(1): 99-120.

[8] Bartlett, W., \& Bukvič, V. 2001. Barriers to SME growth in Slovenia. MOCT-MOST: Economic Policy in Transitional Economies, 11: 177-195.

[9] Baum, J. R., Locke, E. A., \& Smith, K. G. 2001. A multidimensional model of venture growth. Academy of Management Journal, 44(2): 292-303.

[10] Becchetti, L., \& Trovato, G. 2002. The determinants of growth for small and medium sized firms: the role of the availability of external finance. Small Business Economics, 19(4): 291-306.

[11] Castrogiovianni, G. J. 1996. Pre-start-up planning and the survival of new small firms. Journal of Management, 22: 801-823.

[12] Cohen, W., \& Levinthal, D. 1990. Absorptive capacity: a new perspective on learning and innovation. Administrative Science Quarterly, 35: 128-152.

[13] Cooper, A. C., Gimeno-Gascon, F. J., \& Woo, C. Y. 1994. Initial human and financial capital as predictors of new venture performance. Journal of Business Venturing, 9: 371395.

[14] Covin, J. G., \& Slevin, D. P. 1997. Strategy Formation Patterns, Performance, and the Significance of Context. Journal of Management, 23(2): 189-209.

[15] Davidsson, P. 1989. Continued Entrepreneurship and small firm growth. Stockholm School of Economics, Stockholm. 
[16] Davidsson, P., \& Henreksson, M. 2002. Institutional determinants of the prevalence of start-ups and high-growth firms: evidence from Sweden. Small Business Economics, 19(2): 81-104.

[17] Delmar, F. 1996. Entrepreneurial behavior and business performance. Stockholm School of Economics, Stockholm.

[18] Dollinger, M. J. 1999. Entrepreneurship: strategies and resources. Upper Saddle River, NJ: Prentice Hall.

[19] Grant, R. M. 1991. The resource-based theory of competitive advantage: Implications for strategy formulation. California Management Review, 33: 114-135.

[20] Hakkert, R., \& Kemp, R. G. M. 2006. An Ambition to Grow: A multidisciplinary perspective on the antecedents of growth ambitions, EIM SCALES. Zoetermeer: EIM.

[21] Hall, R. H., Haas, J. E., \& Johnson, N. J. 1967. Organizational size, complexity and formalization. American Sociological Review, 32(December): 903-911.

[22] Houston, F. S. 1986. The marketing concept: what it is and what it is not. Journal of Marketing, 50(2): 81-87.

[23] Hult, G. T. M., Snow, C. C., \& Kandemir, D. 2003. The role of entrepreneurship in building cultural competitiveness in different organizational types. Journal of Management, 29(3): 401-426.

[24] Katz, J. (2003), "The chronology and intellectual trajectory of American entrepreneurship education 1876-1999”. Journal of Business Venturing, vol. 18, pp. 283

[25] Lau, C., \& Busenitz, L. W. 2001. Growth Intentions of Entrepreneurs in a Transitional Economy: The People's Republic of China. Entrepreneurship Theory and Practice, 26(1): 5-20.

[26] Low, M. B., \& Macmillan, I. C. 1988. Entrepreneurship: past research and future challenges. Journal of Management, 14: 139-151.

[27] Lumpkin, G. T., \& Dess, G. G. 1996. Clarifying the entrepreneurial orientation construct and linking it to performance. Academy of Management Review, 21: 135-172.

[28] Lumpkin, G. T., \& Dess, G. G. 2001. Linking two dimensions of entrepreneurial orientation to firm performance: the moderating role of environment and industry life cycle. Journal of Business Venturing, 16:429-451.

[29] McClelland, D. C. 1965. N-achievement and entrepreneurship: a longitudinal study. Journal of Personality and Social Psychology, 1: 389-392.

[30] Miller, D. 1983. The correlates of entrepreneurship in three types of firms. Management Science, 29: 770791.

[31] Morris, M.H. and Kuratko, D.F. (2002), Corporate Entrepreneurship, Harcourt College Publishers, Orlando, FL.

[32] Narver, J. C., \& Slater, S. F. 1990. The effect of a market orientation on business profitability. Journal of Marketing, 54: 20-35.

[33] Nelson, R. R., \& Winter, S. G. 1982. An evolutionary theory of economic change. Cambridge, MA: Belknap Press of Harvard University Press.

[34] Nickell, S. 1996. Competition and corporate performance. Journal of Political Economy, 104: 724-746.

[35] Nickell, S., Nicolitsas, D., \& Dryden, N. 1997. What makes firms perform well? European Economic Review, 41(3-5): 783-796. 
[36] Pissarides, F. 1998. Is lack of funds the main obstacle to growth? The EBRD's experience with small and medium-sized businesses in central and eastern Europe: European Bank for Reconstruction and Development.

[37] Riding, A. L., \& Haines, G. J. 1998. Defaulting on loan guarantees: costs and benefits of encouraging early-stage growth. In R. P. D. Bygrave, W. D. Bygrave, N. M. Carter, S. Manigart, G. D. Meyer, \& K. G.Shaver (Eds.), Frontiers of Entrepreneurship Research: 504-518. Wellesley, MA: Babson College.

[38] Samundsson, R., \& Dahlstrand, A. L. 2005. How business opportunities constrain young technology-based firms from growing into medium-sized firms. Small Business Economics, 24(2): 113-129.

[39] Sexton, D., \& Bowman-Upton, N. 1991. Entrepreneurship: creativity and growth. New York: Macmillan.

[40] Shane, S., Locke, E., \& Collins, C. J. 2003. Entrepreneurial motivation. Human Resource Management Review, 13(2): 257-280.

[41] Singh, K. 1992; Women Entrepreneurs, Ashish Publishing House, New Delhi.

[42] Storey, D. J. 1994. Understanding the small business sector. London: Routledge.

[43] Venkataraman, S. 1997. The distinctive domain of entrepreneurship research: An editor's perspective. In J. Katz, \& R. Brockhaus (Eds.), Advances in entrepreneurship, firm emergence, and growth, Vol. 3: 119138. Greenwich, CT: JAI Press.

[44] Wiklund, J., Patzelt, H., \& Shepherd, D. A. 2007. Building an integrative model of small business growth. Small Business Economics.

[45] Zahra, S. A. 1991. Predictors and financial outcomes of corporate entrepreneurship: An explorative study. Journal of Business Venturing, 6: 259-285. 